\title{
System building in the Kenyan electrification regime: The case of private solar mini- grid development
}

Pedersen, Mathilde Brix; Nygaard, Ivan

Published in:

Energy Research \& Social Science

Link to article, DOI:

10.1016/j.erss.2018.03.010

Publication date:

2018

Document Version

Peer reviewed version

Link back to DTU Orbit

Citation $(A P A)$ :

Pedersen, M. B., \& Nygaard, I. (2018). System building in the Kenyan electrification regime: The case of private solar mini-grid development. Energy Research \& Social Science, 42, 211-223.

https://doi.org/10.1016/j.erss.2018.03.010

\section{General rights}

Copyright and moral rights for the publications made accessible in the public portal are retained by the authors and/or other copyright owners and it is a condition of accessing publications that users recognise and abide by the legal requirements associated with these rights.

- Users may download and print one copy of any publication from the public portal for the purpose of private study or research.

- You may not further distribute the material or use it for any profit-making activity or commercial gain

- You may freely distribute the URL identifying the publication in the public portal 


\title{
System building in the Kenyan electrification regime: the case of private solar mini-grid development
}

\begin{abstract}
Given the growing interest in the ability of the private sector to contribute to the goal of providing universal access to energy in developing countries, this study sets out to investigate the practices and business approaches of private actors in the emerging niche of private mini-grid development in Kenya. The paper's analytical focus is on how niche actors are influencing and creating change in the incumbent electrification regime of grid extension to strengthen and expand the niche for private mini-grids. The analysis shows that, in addition to internal niche processes like the alignment of expectations, learning and network building, niche actors actively engage in various forms of institutional work. The greatest emphasis here is on regulatory institutional work in order to influence legal and economic frameworks, but niche actors also engage in cognitive institutional work to enhance acceptance of the niche technology by constructing a shared world view between niche and regime actors. Interestingly, niche actors also engage in normative work to establish positive normative associations with the private-sector model, like equity and social justice. The research concludes that in this case institutional work is collective work drawing on different mandates and relying on different skills and resources.
\end{abstract}

Keywords: institutional work; solar PV, mini-grid niche; system building; Kenya 


\section{Introduction}

As part of the current international push to eliminate energy poverty, decentralised options like mini-grids have become established as a crucial part of the effort to achieve universal access to modern energy services by 2030 (IEA, 2011; Wiemann and Lecoque, 2015). Mini-grids are highlighted as the missing link between large-scale national grid extensions and small-scale solutions like solar home systems and lanterns, being estimated to deliver forty percent of the new capacity needed to meet the goal of universal access (IEA 2011). Rural electrification has traditionally been a matter for state bodies. However, local government bodies and international actors are increasingly stressing the importance of private-sector involvement if the goal of universal access by 2030 is to be met (Bardouille and Muench, 2014; SE4ALL, 2012).

Mini-grid development has a long history in Sub-Saharan Africa. ${ }^{1}$ In Kenya mini-grids are primarily diesel-driven systems set up by the government to connect rural market centres and towns far from the existing grid and projects to provide electricity to communities based on small-scale hydro, PV and wind, alongside systems introduced by NGOs, research institutions and faith-based organisations (Pedersen, 2016). More recently, the technological focus has shifted toward solar-powered systems due to technological advances, price falls (Hansen et al., 2015; IRENA, 2016) and new mobile payment and monitoring solutions (Glemarec, 2012; Rolffs et al., 2015).

A new aspect in this sector is the emergence of private firms which have started operating solar-powered, village-sized mini-grids in rural areas. This started in Kenya in 2011 , but it has since spread to other countries in SSA. These firms resemble each other in being small, start-up enterprises founded by expatriate engineers and business people, their core business being to deliver power through mini-grid systems to rural consumers. The emergence of this group of privately owned firms using new technology and new business models can be conceptualised as an electrification niche that is starting to challenge established ways of planning, regulating and 'doing' electrification in Kenya - what we here call the 'electrification regime'.

While village-based, donor-driven mini-grids have been relatively well researched (Ahlborg and Sjöstedt, 2015; Ilskog et al., 2005; Ulsrud et al., 2015; Nygaard, 2010), knowledge of private-sector involvement in mini-grid development in Sub-Saharan Africa is limited. Research is emerging on the barriers to attracting private-sector involvement in rural electrification (Schmidt et al., 2013; Williams et al., 2015), but sector-wide empirical investigations into firm-level processes of technology diffusion are not available.

In this paper, we aim to shed light on the emerging phenomenon of privately owned mini-grid firms, which are expanding by combining innovative technologies and business models, and to focus on how these companies are creating options for expansion by challenging the existing electrification regime. In studying this emerging phenomenon, the paper aims to provide an empirical contribution and to generate research questions for further research on private mini-grid development. More specifically, we investigate the practices and business approaches of these private firms, how they 'do business', what their

\footnotetext{
${ }^{1}$ Since the turn of the millennium, village-size mini-grids have been established in more than two hundred villages in West and North African countries such as Burkina Faso, Mali, Senegal and Morocco (Nygaard and Dafrallah, 2016; Nygaard 2012, 2010, 2009). In East Africa, until recently village-size mini-grids have not had the same spread, and by 2016 being fewer than fifty (Pedersen, 2016).
} 
strategies are, and how and why they engage in influencing the existing regime in order to diffuse their innovations and strengthen this specific electrification niche.

The structure of the remainder of this paper is as follows. Section 2 provides a brief account of electrification in Kenya. Section 3 presents an integrated analytical framework based on the multilevel perspective (MLP) and the concept of institutional work. Section 4 outlines the research methods that underpin the study. Section 5 presents the electrification regime and examines the semi-coherence and inherent conflicts within it. Section 6 presents empirical findings showing how system building takes place in the private mini-grid niche. Section 7 discusses how the four niche actors are conducting institutional work, deploying different strategies and using different skills to influence institutional settings at the regime level so as to create change in the system. Section 8 concludes the paper.

\section{The context of electrification}

Since the establishment of the rural electrification programme in 1973, rural electrification in Kenya has been guided by the overall priority given to the industrial and productive sectors (Byrne, 2009). The cost of expanding the grid to rural areas has been considered prohibitively high, while demand for energy in rural areas has been regarded as too low to be financially viable (Lee et al., 2016). Rural electrification has been driven by public funding that is highly reliant on foreign aid, especially from USAID, the US development agency. Despite a reorientation towards targeting the poor more effectively through its 'New Directions' policy in the 1970s, particularly in rural areas (Byrne, 2009), rural electrification rates remained low in the following decades, being still below four percent by 2003 (AEI, 2012).

With the de-regulation and unbundling of the energy sector in the 1990s, in which a framework was set out for opening up the sector to the private sector, and the further restructuring in 2006, with the establishment of a Rural Electrification Authority (REA), the government stated its intention to prioritise rural electrification. However, REA's mandate was limited to the electrification of public facilities like trading centres, secondary schools and health centres, leaving the surrounding households unconnected. Thus, although REA's work has led to an increase in electrification by raising the connectivity rates of public facilities from 25\% in 2008 to about 68\% in 2016 (REA, 2016a), overall rural connectivity rates remain low. While national electricity rates rose from 9\% in 2003 to 20\% in 2013, rural electrification rates remained low at 7\% in 2013 (IEA). Likewise, the stock-listing of the distribution company, Kenya Power (KPLC), in 2006 further solidified its role as a company accountable to its investors, leading to a continued and increased focus on urban industrial customers (Kapika and Eberhard, 2013).

\section{Conceptualising regimes, niches and institutional work in electrification}

This section provides the conceptual framework used in this paper. The first section introduces the Multilevel Perspective (MLP) on sustainability transitions, which is used as an overall framework for analysis, and it defines and provides an empirical delineation of the electrification regime and the electrification niches that have been identified. The second 
section describes the conceptual framework for analysing and making sense of systembuilding through institutional work, which is central to the research question.

\subsection{The multilevel perspective}

The multilevel perspective (MLP) (Geels, 2002; Rip and Kemp, 1998) was developed in a European context to analyse how transitions towards sustainability take place following complex, interactive processes at the three levels of landscape, regime and niche. Recently, and in some cases rather uncritically, this framework has also been adopted for research in a developing country context, which typically differs from the situation in European countries in terms of a weaker state apparatus, less transparency and lower levels of legal enforcement, and relatively high levels of economic and social inequality. Of special importance is the circumstance that external donor interventions play an important role and developing countries typically rely more on foreign sources of technology, knowledge and financial resources than is the case for developed countries ${ }^{2}$

Being aware of these challenges in adopting the MLP framework in a developing country context, and paying special attention to the roles of donor interventions and of the foreign sourcing of technology, this paper applies the MLP framework to explore the development of the private mini-grid niche and the processes at work in the Kenyan electrification regime. The MLP emphasises that the alignment of processes at these multiple levels is important in grasping the nature of transitions (Geels, 2005) and that 'both niche processes [...] and changes in the incumbent regime are necessary for understanding the innovation journey of a new technology' (Raven 2006: 581). According to Raven (2006), the greatest prospect for niche expansion and up-scaling is when stability in the niche increases in combination with a situation of relative instability in the regime.

In the literature, there are no clear prescriptions for how regimes and niches should be delineated empirically, but as Markard and Truffer stress (2008: 607), this is important and should be done in a manner that is as 'clear and explicit as possible in order to fully unfold the analytical power'. We acknowledge the multidimensionality of regimes and niches (Geels, 2002), and in this paper the regime and niches are delineated according to: domain of application, technology, business model and ownership. On this basis, we have drawn up three niches for electrification, which are evolving in competition to the mainstream electrification regime in Kenya. The delineation of the niches and the regime is described below, and visualized in Figure 1.

\footnotetext{
2. For a further discussion of the literature critically addressing the challenges in adopting the MLP framework in a developing country context, see e.g. Hansen et al. (2018).
} 


\begin{tabular}{|c|c|c|}
\hline \multicolumn{3}{|c|}{$\begin{array}{c}\text { Electrification regime based on grid extension and mini-grids for larger towns } \\
\text { operated by Kenya Power }\end{array}$} \\
\hline NGO Mini-grid niche & Privat mini-grid niche & Solar Home System n \\
\hline $\begin{array}{l}\text { Mini-grids for small } \\
\text { towns and } \\
\text { settlements owned } \\
\text { by NGOs and } \\
\text { charity } \\
\text { organisations and } \\
\text { operated by village } \\
\text { organisations }\end{array}$ & $\begin{array}{l}\text { Mini-grids for small } \\
\text { towns and } \\
\text { settlements owned } \\
\text { and operated by } \\
\text { private operators }\end{array}$ & $\begin{array}{l}\text { Individual solar PV } \\
\text { systems (SHS) } \\
\text { owned by users } \\
\text { and sold though a } \\
\text { number of } \\
\text { channels such as } \\
\text { M-KOPA, BBOX }\end{array}$ \\
\hline
\end{tabular}

Figure 1. Visual description of the incumbent electricity regime and the three emerging niches for electrification

\section{The electrification regime}

The electrification regime is characterized by KPLC's continued management and control of distribution in grid-connected areas and in mini-grids established in smaller and larger towns located far from the main grid. In this regime, the plan is to reach new consumers through the extension of existing grids operated by KPLC. The focus on connecting industrial users and grid extension is still there, but the Last Mile Connectivity project, launched by the Kenyan Government in 2015 with support from the African Development Bank and the World Bank, is in essence a push to increase connectivity rates among low-consumption households as well by offering highly subsidised connection fees to people living within 600 meters of existing transformer stations. This project was mandated to raise national connectivity rates to 70\% by 2017 (KPLC, 2015).

Within this regime, REA continues to focus on electrifying market centres, schools and health clinics. These are in some cases supplied by individual solar systems, but mainly by extending power lines to target the schools and health centres. In 2016, REA was mandated to establish 25 mini-grids in the smaller towns, which after commissioning are meant to be handed over to Kenya Power for continued operation and management (REA, 2016b). An important characteristic of the electrification regime is the uniform tariff for all customers. This means that customers linked to mini-grids pay the same fees for electricity as customers in the main grid. This is possible due to a high level of cross subsidy within KPLC between customers in the main grid and mini-grids respectively.

\section{The private mini-grid niche}

The private mini-grid niche is a socio-technical configuration characterised by private financing and ownership, advanced hybrid PV-battery technologies, ICT technologies for management and control, and cost-reflective tariffs. This niche, which is the focus of this paper, emerged in Kenya in around 2011, when the first private mini-grid firm was established, followed by three other firms in the following years. This niche will be described in detail in section 6 .

\section{The donor mini-grid niche}

The donor mini-grid niche is characterised by donor-financing, communal forms of ownership, intermediate or appropriate technologies, demonstration of service delivery and 
affordability, and a focus on local partnerships. Experiments in this niche have been ongoing since 1980s, and there are today only a couple of ongoing experiments (Pedersen, 2016).

The solar home system niche

The solar home system niche is characterised by ownership to the system by the user, intermediate financing through pay-as-you go agreements, and a product that mostly delivers lighting, communications (TV) and the charging of mobile phones. This niche has evolved since the beginning of the 1980s (Hansen et al., 2015) and has developed rapidly since 2011, when new socially motivated entrepreneurs, such as M-Kopa and Mobisol, introduced new advanced and cheaper products financed through a pay-as-you-go system serviced by mobile payment systems (Rolffs et al., 2015).

As described in the introduction, the private-sector mini-grid niche, which is the focus of the analysis in this paper, is the most dynamic, being the only niche which is significantly challenging the incumbent electrification regime.

\subsection{System building as institutional entrepreneurship}

Following (Geels, 2004) and Fuenfschilling \& Truffer (2014), this study adopts an institutional perspective to explore change where stability and hence structuration at the different levels of the MLP are conceptualised as different levels of institutionalisation, with the strongest institutionalisation taking place at the landscape and regime levels and the weakest at the niche level. Scott (1995: 33) defines institutions as 'cognitive, normative and regulative structures and activities that provide stability and meaning to social behaviour'. The process of institutionalisation can therefore be viewed as one of gaining legitimacy for new norms, rules and practices.

The current study looks at the strategies pursued by system builders, understood here as key actors (individuals or institutions) who play a role in building functioning niches by undertaking specific activities that contribute to the strengthening of innovation systems around those technologies (Byrne et al., 2014; Ockwell and Byrne, 2015). By drawing on the literature on institutional entrepreneurship (DiMaggio, 1988), especially the concept of 'institutional work' (Lawrence and Suddaby, 2006), we can translate the empirical research question described in the introduction into the following conceptually informed question: How and through what forms of institutional work do actors seek to influence the systems in which they are embedded? The concept of institutional work provides an analytical tool with which to explore 'the purposive action of individuals and organizations aimed at creating, maintaining and disrupting institutions' (Lawrence \& Suddaby 2006: 215). It highlights the effortful and skilful practices of interested actors and is therefore useful in exploring how, through practice, actors institutionalise the niche.

The niche is in its formative phase, where it is characterised by its instability and fragility (Geels, 2005) and its lack of a proper institutional set-up (Kebede et al., 2014). According to the MLP, a niche's viability is influenced by internal niche processes related to the shaping and alignment of expectations, learning and network-building (Schot and Geels, 2008). In addition to these internal niche processes, this study highlights the defining characteristic of niches as being weakly institutionalised spaces where practices, norms, values and routines are competing for legitimacy and where they are not (yet) being mutually constructed by actors in the system (Fuenfschilling and Truffer, 2014). Thus the viability of a niche is contingent on the increased institutionalisation of cognitive, normative 
and regulative structures and activities at the niche and regime levels in support of the niche.

In section 5, the regime will be accounted for in terms of both its historical stability and current de-stabilising factors. Based on the ontology of institutionalism, tensions, conflicts and struggles within the regime are given prominence as a way to account for its semi-coherence. Conflicts and tensions can help expose the instabilities of a regime in which old ways of doing things are being challenged by new actors in the space, thus pointing to areas where institutionalisation is happening and being negotiated and where change is in the making (Fuenfschilling and Truffer, 2014).

In this study, institutional work describes the manner in which private mini-grid developers work to influence their institutional contexts through strategies such as lobbying for regulatory change. As a new organisational model in Kenya, the fully private mini-grid model represents a whole range of novel ways of doing things (e.g. in the form of charging cost-recovery tariffs) and hence a series of weakly institutionalised practices and norms. Institutional work aimed at creating new institutions (Lawrence \& Suddaby 2006) in the sense of winning backing for new norms, practices and rules is therefore of particular interest in order to understand how niche-level actors are working to influence existing institutional settings at the regime level. In this paper we have operationalized the concept of institutional work by drawing on the nine forms of institutional work identified by Lawrence \& Suddaby (2006). Three of these are related to the regulatory pillar of institutions (Scott, 1995), namely advocacy, defining and vesting; three to the normative pillar, namely constructing identities, changing normative associations and constructing normative networks; and three to the cognitive-cultural pillar of institutions, namely mimicry, theorising and educating (Lawrence and Suddaby, 2006; Perkmann and Spicer, 2008).

During the coding and analysis of the empirical material, it was revealed that niche actors were mainly applying the following four forms of institutional work: i) advocacy, which refers to the mobilization of political and regulatory support through direct and deliberate techniques of social suasion; ii) defining, which refers to the construction of rule systems that confer status or identity, define boundaries of membership or create status hierarchies within a field; iii) changing normative associations, which refer to re-making the connections between sets of practices and the moral and cultural foundations of those practices; and iv) mimicry, which refer to associating new practices with existing sets of taken-for-granted practices, technologies and rules in order to ease adoption.

These four forms of institutional work will structure the analysis of system building in section 6 .

\section{Methods}

The study is based on qualitative data drawn mainly from 24 in-depth interviews. Data were gathered during a period of two months from July to September 2015. Twelve interviews were conducted with staff from four mini-grid firms, four with key informants with knowledge about the firms and the sector in general, and eight with regime actors, including representatives of the Energy Regulatory Commission (ERC), the parastatal distribution company, KPLC, the rural electrification authority, REA, and the Ministry of Energy and Petroleum (MoEP). Under an agreement with the case-study firms, they have been anonymised and references to interviews are numbered according to an internal list of interviewees created by the authors. 
Case selection was based on definition and context (Miles \& Huberman, 1994), with the four firms selected due to their characteristics of being well-established, private minigrid developers operating in Kenya. Interviews lasted for between thirty minutes and two hours and were recorded and transcribed. Additional data include observations at mini-grid sites and interviews with customers and their non-connected neighbours during four site visits documented through field notes. Lastly, the study draws upon secondary data in the form of reports, popular media articles and firms' internet websites available as of December 2016. Transcripts, notes and documents were subjected to a qualitative thematic analysis (Braun and Clarke, 2006). Data were coded for emerging patterns and themes in three analytical steps. First, the unique patterns of each firm and differences and similarities between firms were analysed by combining in-firm analyses with a search for cross-firm patterns (Eisenhardt, 1989). Secondly, institutional elements of the incumbent regime of grid extension that were challenged by the private mini-grid niche were identified through coding in order to expose potential instabilities in the regime. Finally, pre-established codes corresponding to the nine forms of institutional work described in section three were applied to the data to analyse how firms and firm actors were conducting institutional work.

\section{Instabilities in the electrification regime}

Since 2011, a de-alignment (Geels, 2005) of the electrification regime has been identified, partly due to landscape forces and partly due to the emergence of a private mini-grid niche. This section describes the most important landscape forces and the most significant tensions observed between institutional elements within the regime, as well as providing an unfolded description of these institutional elements.

\subsection{Landscape forces}

Five landscape forces contributing to the de-alignment of the regime have been identified in the period from 2011 to 2016. First, the UN declared the year 2012 the 'international year of sustainable energy for all' and began pushing for a global agenda to end energy poverty by 2030, led by the Sustainable Energy for All (SE4ALL) initiative. This initiative highlighted minigrids as an important element for reaching the goal of universal access, and it unlocked substantial donor support to mini-grids in Kenya and other SSA countries. Second, there was a general fall in solar PV prices and an increase in the quality of renewable energy technologies, leading to solar PV module prices falling by around $80 \%$ between 2009 and 2015 (IRENA, 2016). This reduction in the cost of PV systems has significantly reduced the level of investment required and thereby improved the business case for mini-grids compared to grid extensions. Third, there was an important increase in the penetration of ICT among rural households living outside Nairobi. For those living below the poverty line, $72 \%$ used ICT in 2011, compared to fewer than 20\% in 2008 (Suri and Jack, 2012).

Integrating ICT into mini-grids has significantly reduced the operating and maintenance costs of mini-grid systems and improved the business case for mini-grids compared to grid extensions. Fourth, there was an increasing focus, driven by climate change, on green and fossil-free investments by the private sector (Climate Change Support Team, 2015; World Economic Forum, 2013), easing access to private investments in PV-based mini-grids. Fifth, donors and development partners, like the UK Department for International Development (DfID), the International Finance Corporation (IFC), the German Development Bank (KfW), the United States Agency for International Development (USAID) and the UN Environmental 
Programme (UNEP), have entered the mini-grid space with a range of initiatives supporting both REA and the private sector in disseminating mini-grids in Kenya.

\subsection{Tensions within the regime}

These five landscape forces contributed to political tensions within the regime. These were exacerbated by stresses arising from the government's adoption of the goal of universal access by 2020 , activities in the private mini-grid niche and the institutional work being conducted by private mini-grid niche actors. The tensions in the regime were a result of conflicting interests, which we observed as conflicting views among regime actors (regulators, policy-makers, rural electrification authorities and the national utility) on whether mini-grid developers were regarded in a positive light as contributors to the goal of universal access, or negatively, as unwelcome actors posing a challenge to the regime.

As one mini-grid developer expressed it, at the political level there has been a great push towards the goal of universal access, and therefore 'anything that works towards that [goal] has got political support'. ${ }^{i}$ Also, there is an appreciation of the need for private-sector financing to achieve the goal of universal access. As an independent regulator, ERC viewed the entry of new actors into the market as ' $a$ win-win development for Kenya that will allow more people to access electricity and make the industry more competitive' (Waruru, 2015). However, although ERC is an independent authority in regulating the market, it is dependent on being given clear policy frameworks by the Ministry (MoEP) in order to make cases that create precedents regarding regulatory issues. In its turn, MoEP, however positive it claimed to be regarding the overall idea of bringing private players into the sector, was apparently unable to act due to a lack of political consensus and was therefore reluctant to come to any hasty conclusions in formulating a policy regarding mini-grids. KPLC, as a parastatal company relying traditionally on its monopoly, had little interest in supporting new players entering the field and indeed argued against it. In interviews with KPLC we uncovered resistance to change based on arguments such as: i) the normative assumption that grid power is superior to decentralised options, ii) practises of costly investments to repair and upgrade the existing network, and iii) the inherent inertia in respect of practices, norms and rules of a parastatal company with a staff of seven thousand. KPLC saw its traditional position, together with REA, as an established and non-challengeable way of delivering cheap (per kWh) power through grid extensions.

\subsection{Contested institutional elements}

In addition to the political tensions within the regime described above, we identified six institutional (regulatory) elements that were contested and that were objected to institutional work being carried out by private mini-grid niche actors. The six elements and the positions adopted are described in detail below.

\section{Licencing}

Since the unbundling of the power sector, KPLC's monopoly has been maintained through its very activities and the absence of regulation in the sector, based in turn on it being the only player in the market. However, the entry of new players into the market in 2015 exposed the lack of clarity in the current legal framework regarding how multiple players are to co-exist in the market. In continuation of its position as a distribution and retail monopoly, KPLC holds a licence to distribute power to the whole of Kenya. Although a minigrid developer should acquire a licence for a restricted area, it will not be granted exclusive 
rights to that area. Indeed, KPLC still retains the right to construct facilities within the same area, regardless of any licences that may be given to other utilities.

\section{Grid integration}

The entry of new players has exposed a lack of clarity on economic and legal issues in a situation in which the national grid is being extended to an area already served by a privately owned mini-grid. The likely options could be: i) that the mini-grid operator would retain ownership and operation of the mini-grid, sell electricity to its customers and buy bulk power from a KPLC transformer: ii) that KPLC would take over the mini-grid and the PV production and operate it as a normal KPLC grid, or iii) that KPLC would take over the grid, while the private operator would still be the owner of the electricity production unit and supply PV power to the grid according to the feed-in tariff (FIT) for solar PV, which has been in place since 2010 (MoEP, 2012). However, details of the rules for assessing the value of assets (mini-grid, PV system), bulk tariffs and consumer tariffs had still not been agreed upon by December 2016.

\section{Tariffs}

The universal tariff of approximately 20 US cents per kWh (ERC, 2013) for domestic users represents a highly institutionalised norm and practice in the current regime, in which price per kWh is viewed as a measure of equity. The saying, 'We are all Kenyans' is used by regime actors to illustrate the point that rural and urban consumers should pay the same for electricity. ii The tariffs charged by private mini-grid operators of 80 US cents to 5 US dollars per kWh form a stark contrast to the universal tariff. From a political point of view, this makes including private actors while maintaining an equitable tariff system a difficult balancing act. The tariffs charged by private mini-grid niche actors are accepted by the ERC due to the pilot status of the projects. However, a lack of clarity over policy means that so far nobody has received approval of their tariffs through ERC.

\section{Connection fees}

Connection fees, as opposed to tariffs, are not regulated by ERC. KPLC has traditionally followed a practice of charging connection fees that reflect the actual costs of connection. Prior to May 2015, when connection fees were reduced to 15,000 KES (173 USD) ${ }^{3}$ under the Last Mile Programme (Mulwa, 2015), the average connection fee in Kenya was 35,000 KES (404 USD), with those in rural areas ranging from 17,400 KES (201 USD) to 46,400 KES (536 USD) (Njuguna, 2012). These fees have proved to be prohibitive for many low-income households wishing to be connected the national grid.

\section{Connecting all versus connecting some}

The issue of balancing accessibility with affordability is a well-documented problem of KPLC's approach (Lee et al., 2016), meaning that large populations are living in close proximity to the national grid's lines without having the financial means to be connected. KPLC and REA follow a model in which only those who can afford the high connection fees in an electrified town or village are connected. The new mini-grid models with connection fees of ten dollars are introducing alternative practises into the system, including models that actively seek to connect everyone within a specific targeted area.

\footnotetext{
${ }^{3}$ Conversion rate as of 1 May 2015: 100 KES =1.16 USD.
} 


\section{Subsidies}

Rural electrification, whether through KPLC programmes or through REA programmes that are handed over to KPLC for operation and management after completion, are effectively subsidised by the government and international donors. Private mini-grid niche actors are so far not receiving subsidies, but they argue that, in order to deliver electricity at a universal tariff, they should have the same access to government subsidies as KPLC.

\subsection{Summing up}

This section has identified five landscape factors that have contributed to instabilities in the electrification regime. It has described the tensions within the regime and the interests and positions of the main regime actors. Finally, it has identified six institutional elements around which main contestations between regime actors and private mini-grid actors evolved. These elements are of importance for understanding the level of re-alignment of the regime and are providing the backdrop for the presentation of private mini-grid niche actors in section six and the analysis of how they engage in system building in section seven.

\section{The Kenyan private mini-grid niche}

This section describes the start-up and evolution of the four firms that constitute the private mini-grid niche in Kenya, and how they are involved in system building.

The four firms constituting the private mini-grid niche resemble each other in experimenting with solar-powered, village-sized mini-grids with battery storage for $24 / 7$ service in rural parts of Kenya. Three of the firms are conventional start-ups, while the fourth was started by an international development corporation with the aim of piloting a for-profit business model. The firms have followed different development paths and are experimenting with different business models, system sizes, types of partnership, types of research and development, types of targeted communities etc. Their mini-grids are between 1.4 and 50 $\mathrm{kW}_{\mathrm{p}}$ in size, with the three conventional start-ups experimenting with tier 2-power ${ }^{4}$ at levels between 50 and 90 watt per household, and the development corporation firm experimenting with higher tiers. The key characteristics of the four firms are listed in Table 1 below.

Table 1. Key Characteristics of four Kenyan private mini-grid firms (the firms have been anonymised)

\begin{tabular}{|l|l|l|l|l|}
\hline & $\begin{array}{l}\text { Ownership } \\
\text { structure }\end{array}$ & Key focus & Business model characteristics & $\begin{array}{l}\text { Up-scaling } \\
\text { strategy }\end{array}$ \\
\hline $\begin{array}{l}\text { Alpha } \\
\text { Beta }\end{array}$ & Private & $\begin{array}{l}\text { Specialising as a } \\
\text { contractor and } \\
\text { supplier for } \\
\text { other firms }\end{array}$ & $\begin{array}{l}\text { Revenue-driven model } \\
\text { Low connection fee } \\
\text { Connecting only households } \\
\text { consuming the greatest amounts of } \\
\text { energy }\end{array}$ & $\begin{array}{l}\text { One project at a } \\
\text { time, depending } \\
\text { on inflow of } \\
\text { funding }\end{array}$ \\
\hline
\end{tabular}

\footnotetext{
${ }^{4}$ Tier 0: no capacity; tier 1: very low capacity (minimum daily supply capacity: 5 watts, 20 watt-hours); tier 2: low capacity ( 70 watts, 275 watt-hours); tier 3: medium capacity ( 200 watts, $1 \mathrm{kWh}$ ); tier 4: high capacity ( 800 watts, $3.4 \mathrm{kWh}$ ); and tier 5: high capacity (2000 watts, 8.2kWh) (IEA and World Bank, 2015).
} 


\begin{tabular}{|c|c|c|c|c|}
\hline & & & $\begin{array}{l}\text { Tariff: } 1.8-5 \text { UDS/kWh } \\
\text { CapEx payback time: } 7-10 \text { years }\end{array}$ & \\
\hline Gamma & Private & $\begin{array}{l}\text { Project and } \\
\text { business } \\
\text { development } \\
\text { (vertically } \\
\text { integrated) }\end{array}$ & $\begin{array}{l}\text { Equity-driven model } \\
\text { Low connection fee } \\
\text { Connecting as many as possible } \\
\text { within an area } \\
\text { Tariff: } 3-5 \text { USD /kWh } \\
\text { CapEx payback time: } 15 \text { years }\end{array}$ & $\begin{array}{l}\text { Roll-out of } 100 \\
\text { sites in the } \\
\text { pipeline }\end{array}$ \\
\hline Delta & In trust & $\begin{array}{l}\text { Generating } \\
\text { knowledge } \\
\text { about the } \\
\text { private-sector } \\
\text { model }\end{array}$ & $\begin{array}{l}\text { Donor-driven model } \\
\text { Low connection fee } \\
\text { Connecting those who are interested } \\
\text { Tariff: } 70-100 \text { KES (0.8-1.2 USD)/kWh } \\
\text { CapEx payback time: } 9 \text { years }\end{array}$ & $\begin{array}{l}\text { No intention to } \\
\text { upscale }\end{array}$ \\
\hline
\end{tabular}

\subsection{Alpha and Beta}

Alpha and Beta were both started by expatriate engineers in 2011 and 2012 respectively. Alpha started its business by focusing on wind power and the local manufacture of small turbines (200W to $1 \mathrm{~kW}$ ) in a factory in Nairobi. In 2013 it changed its focus to develop solar PV mini-grids and has established a solar PV mini-grid production facility in Nairobi employing approximately twenty staff. By December 2016, Alpha owned twelve mini-grids and had installed more than eighteen in Kenya and Tanzania for others (including Beta below). Beta started in 2012 with a core business to develop mini-grids from initiation to completion. As part of its experimentation, it developed a monitoring and metering system because of the lack of such a system in the market. This research and development process took approximately two years and included experimentation with its own mini-grids. This technology has since become Beta's core business. By December 2016, Beta owned two mini-grids and was supplying technology through its monitoring and metering system to around thirty mini-grids (including those installed by Alpha). The implementation approach that characterises both firms is to supply tier 2 power (approximately 90 watt per user and less than 250 watt hours per day) to the most highly energy-consuming segment of rural market towns. Their criteria for choosing which households to connect include a minimum threshold of energy consumption. Their mini-grids are between 1.4 and $6 \mathrm{~kW}_{\mathrm{p}}$ in size, with a tariff of 1.8-5 US per kWh depending on site and calculated to be $20-50 \%$ lower than users' existing spending on alternative fuels. Although, at the outset, the aim of the two firms was to attract funding for their own mini-grid developments, the strategy has since slightly changed for both firms. Acting as contractors, suppliers and service-providers for clients who have access to capital, rather than raising their own capital, has secured them a revenue stream, which in turn has allowed them to expand their business. This business approach, which is to some extent conditioned by the barrier to scaling up funding for their own mini-grid portfolios, has led them to pursue a role as facilitators for the mini-grid sector at large. As a representative of Beta stressed, they are interested in opening up the minigrid sector as widely as possible and in shedding light on aspects of mini-grid development that outside investors and other interested developers know little about. iii They see their own success as dependent on attracting developers and investors into this space while at the same time remaining the main technology provider. Both Beta and Alpha thus see themselves as firms that can enable the sector to grow, create an impact and contribute to expanding the private mini-grid niche by providing critical tools for others in the market. 


\section{Practised business model}

Alpha and Beta are deliberately avoiding the time-consuming and bureaucratic process of obtaining licences and negotiating tariffs with ERC etc. Instead they have established a verbal agreement with ERC that they can run their projects as pilot projects and thereby avoid these bureaucratic processes. Rather than spending time on negotiating with regime actors, they focus on improving operations and services in order to put themselves in a position to be a first choice for potential investors.

Alpha and Beta have developed what Beta refers to as a 'symbiotic partnership' in which Beta is using Alpha as a contractor in projects led by Beta, and Alpha is using Beta as supplier in projects led by Alpha. ${ }^{\text {iv }}$ They have thus developed core businesses that supplement each other and can collaborate in bringing funding into the sector. They also use each other's skills and exchange data and learning across the firms. This close partnership is reinforced by personal friendships across the two firms. Alpha highlighted how, if they experience problems during the testing of their mini-grids, they can just pick up the phone and obtain instant answers or guidance on how to resolve the problem from staff at Beta. ${ }^{v}$ Their opportunistic approach to building networks and partnerships, in which they view quantity and diversity of partners as a strength, can help grow the private mini-grid niche both locally in Kenya and internationally. The larger a client base they can establish, the better business they can generate. They have each developed a broad and to some extent interlinked network of partnerships and client relationships, including universities, NGOs, donors, angel investors and corporate investors, as well as regime actors.

According to Alpha, strong international connections, primarily with the countries of its founders' origins, are crucial in building these strategic partnerships. Partnerships are built and maintained by the firms' directors, who travel abroad regularly and for long periods of time to raise funding and awareness and establish new partnerships.

As part of their strategy to nurture a broad collaborative network of actors both within Kenya and from abroad, these two firms are also pursuing working relationships with regime actors. Alpha and Beta have concrete plans to enter into a collaborative relationship with KPLC, Alpha as a contractor, and Beta as a supplier of technology. In their efforts to stay on good terms with KPLC, the firms have chosen a cautious approach, operating in remote locations far from existing grid lines. Although having eight hours of travel time to sites makes their operations more expensive, this approach was adopted to mitigate risks in relations with KPLC by refraining from approaching sites of potential conflict with KPLC.

Beta in particular is focusing on generating data and knowledge to support its business. Beta has two strategies: i) doing research to increase general knowledge about the private mini-grid model in the network; and ii) developing a business asset consisting of a world-class database. Through university and research grant funding and angel investor funding for research activities, Beta generates knowledge and data on the private mini-grid model. In Beta's view, commercial investors will not invest in these experimental projects unless someone has documented the business model and established credible and robust evidence for investors to base decisions on. This goes hand in hand with their aim to open up the sector to as many actors as possible. Beta is, for example, working on a research paper with an angel investor based on data collected from their installed mini-grids with the aim of generating key success indicators for mini-grids which they can use in their work advising new investors in the field. 
Through their metering and monitoring product, Beta generates data from its pilot projects, which are analysed in order for the results to be shared with or sold to other interested developers and investors. Beta is working to build up a full range of data representing different types of business case so as to be able to cater for future potential investors with varying objectives ranging from the purely commercial to social impact. This database has already become an asset for Beta, as it is being approached spontaneously by investors who are interested in developing mini-grids but who lack experience of and specific knowledge about the market. This approach represents an ad hoc business development strategy where each new project is unique and where a business is built up from project to project based on the practical requirements of investors.

\subsection{Gamma}

Gamma was started in 2011. Since then it has been successful in attracting commercial capital through various funding rounds, including seed, venture and equity capital. Its access to large-scale funding has allowed it to set a long-term vision based on a three-phase scaling-up strategy. Phase one included experimentation with and the testing of its model in four pilot sites of varying sizes $(1.4,10,20$ and $50 \mathrm{~kW}$ ). Phase two, which was being implemented by December 2016, includes experimenting with the roll out of a standardised yet locally adapted mini-grid to a hundred sites in the country. This activity will lay the basis for phase three, which is a further expansion of its activities both in the region and globally. Access to large-scale financing has also allowed it to attract senior staff with valuable knowledge about the Kenyan energy sector. In addition, Gamma's business model differs from those of Alpha, Beta and Delta by being vertically integrated, with integrated R\&D functions involving software and hardware solutions, financing, project development, and operations and management. Like Beta, Gamma has developed a proprietary metering and monitoring solution, which is at the core of its mini-grid system.

\section{Practised business model}

Gamma's model is to connect as many households as possible within its targeted operating areas. Its connection fee of 2500 KES (29 USD) includes a start-up package with light bulbs. There is an extra cost of 5000 KES (58 USD) for wiring, which is provided as a loan repayable in daily instalments of 70 KES (0.8 USD) over a period of two years. Gamma's model is designed to make connections available and affordable to as many consumers as possible and thus to saturate the areas in which it operates. This includes, for example, leaving ten percent of connections vacant in their systems for potential future customers and cross-subsidising between consumers in the system. Gamma is constructing mini-grids to be grid-ready, thus being able to accommodate large loads and to meet the standards of the national grid. This in turn means that Gamma is future-proofing its systems by overdimensioning from the outset. Gamma has also established a buffer zone of 600 meters from existing KPLC infrastructure as part of its selection criteria for new sites.

With its mission to build up a strong market position through a vertically intergraded approach based on turnkey mini-grid projects, Gamma has kept a closed and protective approach toward other actors in the private mini-grid niche. It is not reliant on other actors in the niche but instead is building networks based on strategic ties to overseas investors and business partners such as suppliers of branded technologies and investors. Through previous start-ups, the firm's founders have acquired links to finance and knowledge 
networks and are driven by previous experience within the telecommunications market and with mobile charging solutions. As part of its approach to building up a strong market presence in Kenya, Gamma has made a number of strategic local recruitments. Thus it has recruited an ex-KPLC and ex-REA director to head the East Africa division with a total of 25 years' experience in the two organisations, as well as an operations manager with 15 years' experience in the telecoms sector. The operations manager, who is in charge of Gamma's hundred-site roll out, was headhunted directly from the telecom construction sector and has a long professional background in telecom site construction. Furthermore, Gamma has managed to bring on board an Oscar-winning actor and distinguished climate change advocate as a special advisor to the firm.

In order for Gamma to move from experimenting with four sites to developing a portfolio of one hundred sites, it is dependent of the support of regime actors, with whom it has initiated bilateral and multilateral meetings. As a platform for making its viewpoints heard, these meetings take the form of 'discussion forums' to which representatives from ERC, MoEP, REA and KPLC are invited. According to Gamma, the objective at a general level is to 'figure out how this will work' and to agree on a direction for mini-grid development. ${ }^{\text {vi }}$ These discussions are unprecedented, and agreements will hence play a part in setting precedents for the rest of the niche. In these talks, Gamma is addressing specific issues arising from its experiments, and the talks are guided in particular by two themes: legal issues, including licensing and rights to operate in areas of shared interest between Gamma and KPLC; and economic issues, including tariff setting and broader negotiations on the business prospectus.

Due to uncertainty over the frameworks for how new entrants in the distribution market should be included under existing policies, Gamma is seeking to find concrete solutions relating to its operations for how to coexist with KPLC. Gamma is therefore seeking to lower the level of uncertainty by interacting with, negotiating with and agreeing upon terms directly with KPLC. '[...] with KPLC specifically we want to lay the framework for what happens when we meet. Do you buy us out? Do we buy power from you and continue powering the village? You know, there are so many scenarios, so we want to understand what these scenarios are and [would] actually like to have some agreed options. ${ }^{\text {vii }}$

Tariff negotiations and broader negotiations on the overall business prospectus, and more specifically the issue of returns on investment, are important for Gamma if its tariff is to be approved. Given that tariffs are a contested topic, and with the 'private mini-grid model(s)' not being well understood among the different regime actors, Gamma makes an effort to present its business prospectus and to explain its proposed business model to ERC and MoEP to convince them of the appropriateness of the assumptions involved, including regarding tariffs and returns on investment. This is done concretely by putting forward the feasibility studies underpinning its business model for review and scrutiny by legal and economic experts at the ERC. It is a committee of the ERC that is ultimately responsible for approval of the tariff.

Central to the way in which Gamma has gained access to regime actors has been its recruitment of its East Africa director. This has helped Gamma directly in its negotiations with ERC, KPLC and MoEP, especially in the matter of obtaining a licence. The director has a long working relationship with actors in MoEP, ERC, REA and KPLC and, as an ex-director of the latter two organisations, has direct access to the energy minister. Insights into 'what works politically and what doesn't work politically', as well as the credibility he has built up as a director of the two organisations, has helped Gamma address the political issues 
involved in establishing and growing the firm. viii This has also helped it reduce resistance to the firm from KPLC, which did not object to its application, as KPLC was included in the licensing process from the beginning.

Gamma is active in marketing the firm through the Kenyan media and engages in a mediated dialogue with regime actors by expressing its views on specific policy issues through the media. This is done by, for example, expressing the view that, just as KPLC has access to funds to assist with the costs of lighting up rural areas, so should smaller utilities also be able to tap into concessional loans, government guarantees and other financial support.

\subsection{Delta}

Delta was started by the German federal development corporation (hereafter 'the corporation') in 2014 as a 'special purpose vehicle' and a private company in trust. The Delta project is a single experiment, which there is no intention to scale up. The mini-grid is a 50 $\mathrm{kW}$ system supplying tier 2-5 power to the residents of a remote market town. As of August 2015, twenty people had been connected, with more to follow. The firm and its operations are fully funded by donor finance through the German government. This company could be perceived as belonging to the donor mini-grid niche, but because the ultimate goal of the Delta project is to imitate a private business model in order to generate data and insights about this model and to feed this learning into national advisory processes and policymaking, we have found it most appropriate to include it in the private mini-grid niche.

As Delta is financed by donor money and not by private finance, an agreement has been drawn up providing that the mini-grid will be handed over to REA at the end of the project phase. This arrangement also means that Delta is simulating a private model rather than being a private model. This simulation includes approximating the assumptions and figures that underpin its business model. This model simulates an approach based on $20 \%$ equity from the mini-grid developer and an $80 \%$ loan, the loan being conditioned by a $10 \%$ interest rate, which, according to Delta, is ' $a$ little bit low', as Kenyan commercial banks lend at higher rates. ${ }^{\text {ix }}$ Furthermore, based on its own feasibility study, Delta has decided on a maximum tariff of 100 KES (1.2 USD) and a break-even point of nine years, though excluding the cost of network infrastructure (because the system will be handed over to REA), and with a situation of negative net present value. This exemplifies how, although attempting to simulate a private model, actual conditions for Delta may vary from those of 'real' private actors.

\section{Practiced business model}

Although it is possible to operate mini-grids at the pilot stage without having a licence or permit from the ERC, ${ }^{5}$ as in the case of Alpha and Beta, Delta initiated the cumbersome licensing process as part of its aim to generate knowledge about the barriers to private sector-led mini-grid development. During the licensing process, KPLC raised an objection to the application, claiming that the proposed mini-grid site was in conflict with its own plans to expand into the area. However, KPLC withdrew the objection when it was informed about the arrangements for the project involving assets being handed over to REA after project

\footnotetext{
${ }^{5}$ According to the 2006 Energy Act, a permit is required to distribute electricity when the installed capacity is less than 3 MW. According the draft Energy Bill from 2015 (not yet adopted), a licence is required to distribute electricity independent of size (GIZ 2015). Companies have therefore applied for a licence.
} 
completion, the system being operated and managed by KPLC henceforward. Based on its experience with the Delta mini-grid, the corporation has published a guidebook on the licensing process (GIZ, 2015), as well as one on the site selection process and a tool for calculating input into a feasibility study. It has also made various project documents like customer contracts, complaint forms etc. publicly available.

The corporation highlights how the policy framework and environment for mini-grid development is not very conducive to private-sector involvement, and it sees itself as instrumental in improving the policy framework for private-sector mini-grids and taking on the role of guiding regime actors in making decisions. As a long-term donor agency in Kenya, the corporation has already established links with the various regime actors. It has also drawn up various draft policy documents based on the data generated in the Delta project together with the MoEP and the Kenya Private Sector Alliance (KEPSA) as input into policy formulation processes. These include concrete suggestions in the form of concept notes for how a cross-subsidy scheme and a new grid code could be designed. The corporation is arguing for using the rural electrification fund to cross-subsidise private-sector mini-grids. The rural electrification fund, which is financed through a five percent levy on the monthly electricity bill, is included in the proposed energy bill, which has been sent to the Senate for review (Shiundu, 2016). The corporation is accordingly suggesting tapping it to subsidise the private sector. In addition to working directly with MoEP, the corporation is cooperating with associations like KEPSA, who are lobbying on behalf of Delta and the rest of the private mini-grid sector.

In the town where Delta operates, it has outsourced all customer relations work to a German NGO, which has set up complaints procedures and has encouraged local villagers to form a committee in charge of communications with Delta and the corporation about any issues that arise.

\section{Processes of system building}

Based on the presentation above, this section will discuss how the expansion of the private mini-grid niche is supported by traditional niche processes; how the electrification regime is being challenged through institutional work being carried out by niche actors, and how institutional work is contingent on the resources and skills available for various niche actors.

\subsection{Internal niche processes}

\section{Alignment of expectations}

SE4ALL's commitment to achieving universal access by 2030 , and the even more ambitious goal of the Kenyan government to reach universal access by 2020 , provide a global vision for increased rural energy access through alternative measures like private mini-grids. However, when it comes to attracting finance to the private mini-grid niche, expectations seem to be shared only among particular types of investors. The firms have managed to attract finance for their experimental projects from particular types of investors. In addition to their own investments and to some extent grant funds, investors include angel investors and large well-established companies within the energy field, including a European electrical appliances manufacturer, a European utility and an American utility-scale solar power company. Commercial loans from conventional banks, on the other hand, have not (yet) become part of the firms' financing portfolios. This indicates that expectations are shared among a group of like-minded investors with a background in the energy sector who are seeking to diversify their portfolios to include investments with a social impact. However, 
positive expectations of the viability and impact of the private mini-grid model have still to be taken up and shared among more conventional financing actors.

Among the firms there is a high degree of alignment of visions and beliefs. The firms are driven by a social mission to deliver electricity to unconnected populations, and they view the economic viability of their businesses as the means to achieve that end. In terms of technological solutions as well, the firms are all relying on highly advanced technological components and systems, which they view as crucial for their success. However, in terms of strategies, agendas and interests, the alignment of expectations between the firms is less clear. Gamma's aim of connecting everyone, as contrasted with Alpha and Beta's approach to connect only the most highly energy-consuming households in a village, provide an example where further learning both within and across individual projects can help articulate and specify expectations further, as the outcomes and consequences of the various approaches are still poorly understood.

\section{Networks and learning}

For all four firms, the viability of their business models is dependent on a careful understanding of user patterns, user preferences, user affordability, data generation and insights into how to optimise their models according to the identified patterns. By working with universities and research-oriented investors, Beta is supporting the codification and diffusion of this learning. Alpha and Beta are working to generate knowledge about the 'private mini-grid model', as they see this as a way to open up the sector more widely, bring in more investors and increase their networks of clients. By collecting a whole range of data based on different implementation models with varying degrees of commercial viability, they are building up a large database to cater for any type of potential collaborative investor in the future. Alpha and Beta share insights and knowledge obtained from experiments, and the two firms see the codification and dissemination of knowledge as a means to increase its impact in the niche. For Delta, the codification and dissemination of knowledge is part of its mandate and raison d'être. Gamma, on the other hand, being conditioned by its vertically integrated approach, is taking a closed approach where learning is not shared across the niche. Data and insights from pilot projects are seen as firm secrets.

The Ministry of Energy has made arrangements to gather together the private-sector actors with the aim of collecting input from private-sector stakeholders in relation to policy development. However, there are no formal or informal initiatives or platforms for sharing knowledge within the niche. Alpha's, Beta's and Gamma's primary networks stretch back to the USA and Europe and are highlighted by firm representatives as one of the reasons for their success in attracting funding to the niche. While Alpha and Beta are relying on a broad range of partners and collaboration, characterised by ad hoc project-to-project interaction, Gamma is developing its technology and business model in collaboration with one 'strategic investor from the solar industry'. Its strategy in teaming up with a large solar utility player is based on the active participation of the partner in the innovation process. Furthermore, Gamma has gained access to specific expertise and expanded its understanding of costreduction strategies, logistics and financial strategies.

This section shows that, while knowledge generation is a crucial part of business development for the firms, networks between firms across the niche are not (yet) well developed, and knowledge exchange among the firms is only limited. Rather, the firms are operating with strong ties back to overseas partners, and it is these with whom knowledge is exchanged. At the same time, they have established their businesses based on data-driven 
technologies where knowledge and learning about particular technologies are kept within the firms. In this way, the firms tend to operate more like competitors competing for market share rather than as collaborators. This observation of strong international linkages and weak internal niche processes is also found in other developing country contexts (Hansen and Nygaard, 2014), but more research is needed to hypothesize about the importance of weak internal niche processes in a developing country context (Binz and Truffer, 2017)

From this analysis of niche-internal processes, the next section will focus on the niche-external processes that are at play when system building takes place as a result of niche actors' active involvement in institutional work in order to create new practices, rules and norms in support of the niche. These processes will be discussed below.

\subsection{System building through institutional work}

This section will discuss the ways in which the electrification regime is being challenged through processes of institutional work carried out by private mini-grid niche actors. As outlined in the conceptual framework, institutional work takes various forms, which will be used to structure this discussion. The following three subsections discuss how the regime is being challenged through i) regulatory forms of work in the sense of advocacy and defining; ii) cognitive forms of work in the sense of mimicking; and iii) normative forms of work in the sense of changing normative associations.

\section{Regulatory work}

Advocacy, understood as 'the mobilization of political and regulatory support through direct and deliberate techniques of social suasion' (Lawrence and Suddaby, 2006), takes the form of bilateral meetings in which private mini-grid niche actors negotiate various issues, taking their point of departure in their specific business cases. Through the meetings they have initiated with MoEP, KPLC and ERC, and through collaboration with the advocacy organisation KEPSA, Gamma and Delta are campaigning for political and regulatory support through representation of their interests and direct and deliberate social persuasion.

Part of this work also entails defining, understood as 'the construction of rule systems that confer status or identity, define boundaries of membership or create status hierarchies within a field' (Lawrence and Suddaby, 2006). Niche actors, for example, need to convince ERC and MoEP of the appropriateness of their model in order to have their tariffs approved by ERC. This process includes revealing and explaining elements of their economic models, such as returns on investment and tariff levels, as well as answering questions and explaining the rationales underpinning the model. These negotiations thus become part of a process to formalise new rule systems with regard to the niche. Similarly, by being involved in developing specific concepts of cross-subsidisation and grid codes for mini-grids together with the Ministry of Energy, Delta and the German development corporation are engaging in defining work to establish the parameters of future institutional structures and practices.

By establishing the special purpose vehicle of Delta, the corporation has acquired a new legitimacy to speak on behalf of private-sector mini-grid developers and to use its access to policy-makers to advocate the case for mini-grids. In its efforts to formalise the underpinnings of the private mini-grid model, it has also produced material to explain the advantages of its business model to regime actors. The corporation, in particular, creates templates and formal documents representing this model, thus targeting and seeking to 
influence both the legal and economic instabilities in the regime by suggesting specific solutions on issues of licensing, grid-integration, tariffs and subsidies.

Gamma and Delta, by directing their advocacy towards regime actors, are acting as front-runners in setting precedents for both themselves and other actors in the niche. In particular, their success in obtaining a licence has constituted a form of persuasion through practice, and they have now paved the way for later applicants to follow.

Gamma is seeking to promote its agenda towards the regime not only through bilateral or multilateral meetings with regime actors, but also by reaching out to a broader set of actors through the media to create pressure on the regime and to gain support for its work. By inviting regime actors to engage in initial discussions about its work and business model, and by engaging in direct negotiations with regime actors, Gamma is building what Markard et al. (2016) refer to as advocacy coalitions across the niche and regime level to enhance the chances of change materialising. Furthermore, by linking up with an established 'climate hero', Gamma is seeking to increase its legitimacy internationally, while by recruiting an ex-KPLC/REA director with already established legitimacy in the national energy sector, it is acquiring instant access to the assets this person represents in the form of access to policy-makers, political know-how, in-depth knowledge of the sector and established relationships with regime actors. Gamma's inclusive and collaborative approach towards regime actors has reduced resistance from the regime to its experimentation and upscaling efforts. KPLC, for example, did not object to the application process for the licence as it did with Delta. Although Gamma operates in close proximity to KPLC and thus establishes itself as a competitor, its inclusive approach supports a narrative about niche actors being contributors to the overall goal of universal access, rather than as competitors to the existing regime.

\section{Cognitive work}

An important but less visible part of private mini-grid niche actors' institutional work is conducted in terms of mimicking, understood as 'associating new practices with existing sets of taken-for-granted practices, technologies and rules in order to ease adoption' (Lawrence and Suddaby, 2006). In this case, mimicking is closely linked to applying existing technologies and practices from the telecoms sector to the mini-grid niche.

The mini-grid firms have adopted existing practices and technologies from the telecoms sector in order to reduce investment costs and operating costs. By employing an operations manager from the telecoms industry and adopting and imitating large-scale implementation methods through the translation and transfer of knowledge, ideas and experience from the telecoms construction sector, Gamma has reduced its investment costs. Secondly, it has reduced its operating and management costs by introducing mobilephone technology for the real-time operation, management and surveillance of the systems. In addition it has ensured future integration with the main grid by using certified components and the same grid-code construction standards as those used by KPLC.

Besides the technological benefits of including existing technological components in the new private-sector mini-grid technology, our analysis shows that there is a less visible, but important element of institutional work embedded in this technology choice in the form of mimicking.

Mimicking the use of the popular mobile payment systems for payments in minigrids is a way of gaining popular acceptance for the system and thus easing adoption. Using mobile telephone technology for communication with and control over the system is seen 
as a 'modern' and acceptable practice. Similarly the use of grid-standard components conveys the message that mini-grid operators' approaches to delivering electricity are not dissimilar to those associated with the national grid. These firms are thus creating links between new practices related to mini-grids and already established practices related to extensions of the national grid. In this way they are reducing rather than emphasising the gaps between the regime and the niche, which can help lower the potential barriers to future integration into the national grid.

\section{Normative work}

Private mini-grid niche actors conduct normative institutional work by changing normative associations, understood as 'Re-making the connections between sets of practices and the moral and cultural foundations for those practices' (Lawrence and Suddaby, 2006). With respect to tariffs in particular, niche actors have had a strong interest in changing normative associations, in this case to discursively change the way the price of electricity is defined and perceived within the regime. This is due to the fact that niche actors charge four to twenty times more than the national universal tariff for electricity. Rather than supporting the conventional view of the price of electricity as a price per unit (KES/kWh), niche actors are instead working to create a narrative of a holistic pricing model. Through this holistic pricing model, they seek to convey the idea that the private mini-grid model provides a better service than what is already available (kerosene, diesel and expensive phone charging) and at a lower price than what people are paying for these inferior services. In addition, by charging low connection fees and low wiring costs, , from a holistic cost point of view they provide cheaper power than what is available from KPLC over a period of many years. Therefore, by arguing for a holistic pricing model, niche actors are questioning the normative associations underlying the uniform tariff and are seeking to reformulate the normative associations related to their models.

Gamma has applied a second approach to changing normative associations by connecting as many people as possible within its target areas. This has acted to create a positive narrative about its model both in the targeted community and among external actors, including regime actors, investors and donors. By applying this approach, Gamma is improving its own business model in terms of i) potential growth in the future, ii) keeping the costs per connection down and iii) the possibility to make high-consumption customers subsidise low-consumption ones. At the same time, Gamma also argues that this is the morally right thing to do and in this way is creating normative connections between its sets of practices, including the moral and cultural foundations of these practices and its mini-grid model. Gamma's model, based on saturating targeted areas, is challenging the conventional ways of doing business represented by REA and KPLC. Gamma's model is also contrasted with other private mini-grid models, where only the $10-20 \%$ of the most energy-consuming households in a community are connected. Through this approach, Gamma is associating its model with norms of human welfare and affordability, rather than traditional notions of the private sector, such as turning a profit, and is thus targeting the world views of both regime actors and the general public.

\subsection{Institutional work contingent on business models, skills and mandates}

Scholars have highlighted how institutional work requires resources and skills that are available to some actors and not to others (Lawrence and Suddaby, 2006; Perkmann and 
Spicer, 2008). This section will reflect on how the various system building processes discussed above are related to the firms' various skills, resources, business models and mandates.

Alpha and Beta are refraining from carrying out institutional work targeted directly at the regime. Instead, system building is primarily focused on creating room for manoeuvre and on strengthening their positions within the private mini-grid niche by forming networks and facilitating learning. They are carefully prioritising the time and resources they need to develop client relationships and improve their businesses over the time-consuming and bureaucratic processes of obtaining licences and tariff negotiations directly targeted at the regime. This approach seems to be conditioned by their revenue-driven business model, which has led them to pursue a role as facilitators for the mini-grid sector at large. This business model is to some extent conditioned by the barrier to scaling up funding for their own mini-grid portfolios and is hence an expression of a limited access to financial resources. Furthermore, their specialisation as a sub-contractor and a supplier respectively and their aim of becoming a sub-contractor and supplier for KPLC has led them to construct mini-grids far away from existing KPLC infrastructure, thus pursuing a non-confrontational approach towards regime actors as a way to mitigate the risks to their business.

Delta, on the other hand, although established as a private firm with a CEO from the private sector, is firmly embedded within a 'donor discourse' with a business model that reflects the skills and resources of the development corporation. Its mandate is to act as a facilitator of the policy process. As a result, it needs to establish and define a balance between investor considerations, government considerations and customer considerations. In its work it relies on its already established credibility as a well-established development corporation on the political scene in order to acquire political influence.

Gamma, with its access to finance and its claimed ability to scale up its operations, is in a position where it is forced to engage with regime actors. As a strategy to increase its chances of success, it has taken a very direct approach towards regime actors by relying on a broad set of skills and resources. Its access to finance has made it possible to attract highly skilled staff, which in turn supports its efforts to influence the regime through a combination of regulatory, cognitive and normative institutional work. As Gamma has decided to build its mini-grids in close proximity to existing KPLC infrastructure, political skills are leveraged to push for negotiations with MoEP and KPLC on issues like licensing and future integration into the grid. Technical skills are leveraged to create a shared understanding between regime and niche actors through, for example, mimicking standards and large-scale implementation models. Lastly, cultural skills are leveraged to create a normative and moral narrative about the private mini-grid model.

The approaches to system building described above may appear to be a set of rather individual activities, but nevertheless the findings suggests that system building is taking place as a result of the combined efforts of actors in the niche and that both internal and external niche processes play a role in niche-building. Actors are shown to be involved to different degrees in system building, the form of which actors engage in being conditioned by the available skills and resources of the firm, applied business models and mandates. 


\section{Conclusion}

This paper has offered an empirical account of how a group of privately owned startup firms has challenged the conventional way of carrying out rural electrification in Kenya. While little happened on the ground at the beginning of the millennium, or even after the establishment of the Rural Electrification Authority in 2006, the emergence of this small group of private firms, together with donor-supported initiatives, has, in a relatively short space of time, changed the thinking, planning and regulation of 'doing' rural electrification in Kenya. That said, the development trajectory for the private mini-grid niche is still uncertain, and it is still too early to judge whether the current interest in private-sector mini-grids will lead to a fundamentally different way of carrying out rural electrification in Kenya.

In this regard, the paper has pointed to a number of emerging questions with respect to the long-term sustainability of these business models. Will private mini-grid developers have access to same level of subsidies as the mini-grids implemented by REA, and if not, will they be able to attract sufficient external capital and survive? Will private business operators be able to make a profit out of the popular 'connect all' strategy when publicly driven electrification schemes have not found it profitable to connect the poorest segments of the population? And how will private businesses be able to balance the dual objective of earning a profit and providing affordable electricity to the poor?

Drawing on the multilevel perspective, these questions are relevant to understanding whether the private mini-grid niche will be able to upscale and become a sustainable, complimentary approach to rural electrification in the long term, and they also call for further research, both now and along the future path of development. At this point, however, with a relatively stable regime combined with relatively strong and broad social networks and niche actors able to learn effectively from experiments, the niche seems to represent what Raven (2006) refers to as a promising technology. Given the increasing institutionalisation of niche rules, practices and norms (niche stability), combined with a relatively stable regime, the niche should be able to grow, though rapid expansion may be prevented by regime stability. Regime-stabilising factors, like donor-supported mini-grids established by REA and handed over to KPLC, donor-supported grid extension programs, existing investment in current grid-infrastructure and government-backed guaranties for KPLC initiatives, may in this regard limit opportunities for further niche expansion. Under this scenario, niche actors will compete directly with the regime actors for market share (Raven 2006). Alternatively, if regime stability decreases and the niche become increasingly stable, the niche can end up as a problem solver, with regime actors proactively supporting the niche, thus leading to its rapid expansion.

In this regard, institutional work by niche actors targeting the regime may prove crucial in creating the conditions for change. By drawing on the concept of institutional work, this paper has provided insights into the processes at work during the first important stages of private mini-grid development. It has shown how niche actors are focusing on a dual strategy of expanding the niche though niche-internal processes while at the same time trying to reform and challenge the existing regime's conditions.

The paper has also shown how actors within the niche are targeting openings in the form of tensions and conflicts within the existing regime to encourage and push for the creation of niche-supporting institutions in the sense of rules, norms, values and belief systems. Niche actors focus primarily on rule-based institutional work, such as advocacy and defining, which is targeted at policy-makers in order to improve the legal and economic frameworks for niche development. This is fully in line with the general focus of 
development actors and policy advisers on the role of an enabling framework that stresses the legal and economic aspects (UNDP, 2011; UNEP, 2015; Williams et al., 2015).

Less visibly, however, niche actors also engage in cognitive institutional work in the sense of mimicking, with the objective of internalising the assumptions underpinning the private mini-grid model and thus constructing a world view that is shared between niche and regime actors. Interestingly, niche actors also produce a substantial amount of normative work, for example, by trying to discursively change the way the price of electricity is defined and perceived both among consumers and within the regime. This work of the niche actor has been deemed necessary in order to create links between the private model and 'positive' normative associations like equity and social justice, which are normally associated with public-sector engagement.

The analysis further shows that not all actors in the niche engage to the same extent in these purposive practices targeted at creating change in the regime. These empirical insights contribute to the discussion of why some actors engage in institutional work while others do not (Ritvala and Kleymann, 2012), as well as to debates over the roles of skills and resources when actors perform institutional work (Lawrence and Suddaby, 2006; Perkmann and Spicer, 2008). While some actors are mostly engaged in niche-internal processes, other actors are equally engaged in niche-external processes, conducting institutional work targeted directly at the regime level. This indicates that different business approaches and different skill-sets within these firms are determining the way in which both firms and individuals engage in system building. Their attempts can be viewed as a collective effort in which actors who are embedded in different world views, draw on different business models and have different mandates are relying on different skills and resources and are thus engaging in different types of system building. These findings concur with those of (Greenwood and Suddaby, 2006), according to whom institutionalisation processes are rarely if ever achieved by a lone institutional entrepreneur or a hero entrepreneur, as suggested by Hellsmark and Jacobsson (2009). These findings also open up reflections into whether diverse business approaches and a broad representation of skills and resources among firms operating in a niche (at least in the early niche formation stage) are conducive to successful niche formation.

By emphasising the practised work of system builders, the study contributes empirical insights into the role of actors in processes of how niches contribute to changes in the behaviour, practices and routines of existing regime actors (Schot and Geels, 2008) and thus to the ongoing effort to understand agency within the framework of transitions theory (Fuenfschilling and Truffer, 2016; Jolly and Raven, 2015). The paper also provides new insights into how niche actors complement and combine niche-internal and niche-external processes in driving the expansion and scaling up of new niches (Raven et al., 2016). 


\section{Literature}

AEI, 2012. Institutional approaches to electrification: the experience of rural energy aagencies/rural energy funds in Sub-Saharan Africa. The World Bank Group, Washington D. C.

Ahlborg, H., Sjöstedt, M., 2015. Small-scale hydropower in Africa: Socio-technical designs for renewable energy in Tanzanian villages. Energy Res. Soc. Sci. 5, 20-33. doi:10.1016/j.erss.2014.12.017

Bardouille, P., Muench, D., 2014. How a new breed of distributed energy services companies can reach $500 \mathrm{~mm}$ energy-poor customers within a decade: a commercial solution to the energy access challenge.

Binz, C., Truffer, B., 2017. Global Innovation Systems-A conceptual framework for innovation dynamics in transnational contexts. Res. Policy 46, 1284-1298. doi:10.1016/j.respol.2017.05.012

Braun, V., Clarke, V., 2006. Using thematic analysis in psychology. Qual. Res. Psychol. 3, 160.

Byrne, R., Ockwell, D., Urama, K., Ozor, N., Kirumba, E., Ely, A., Becker, S., Gollwitzer, L., 2014. Sustainable energy for whom? Governing pro-poor, low carbon pathways to development: lessons from solar PV in Kenya. STEPS Centre, University of Sussex, Brighton. doi:10.1007/978-0-85729-268-1

Byrne, R.P., 2009. Learning drivers: Rural electrification regime building in Kenya and Tanzania. PhD Thesis. University of Sussex.

Climate Change Support Team, 2015. Trends in private sector climate finance: report prepared by the climate change support team of the United Nations Secretary-General on the progress made since the 2014 climate summit. United Nations (UN).

DiMaggio, P.J., 1988. Interest and agency in institutional theory, in: Zucker, L.G. (ed.), Institutional Patterns and Organizations: Culture and Environment. Ballinger, Cambridge, pp. 3-21.

Eisenhardt, K.M., 1989. Building Theories from Case Study Research. Acad. Manag. Rev. 14, 532-550.

ERC, 2013. Approval of schedule of tariffs set by the Energy Regulatory Commission for supply of electrical energy by Kenya Power and Lighting Company Limited pursuant to section 45 of the Energy Act, 2006.

Fuenfschilling, L., Truffer, B., 2014. The structuration of socio-technical regimes - Conceptual foundations from institutional theory. Res. Policy 43, 772-791. doi:10.1016/j.respol.2013.10.010

Fuenfschilling, L., Truffer, B., 2016. The interplay of institutions, actors and technologies in socio-technical systems - An analysis of transformations in the Australian urban water sector. Technol. Forecast. Soc. Change 103, 298-312. doi:10.1016/j.techfore.2015.11.023

Geels, F., 2002. Technological transitions as evolutionary reconfiguration processes: A multilevel perspective and a case-study. Res. Policy 31, 1257-1274.

Geels, F.W., 2004. From sectoral systems of innovation to socio-technical systems: insights about dynamics and change from sociology and institutional theory. Res. Policy 33, 897-920.

Geels, F.W., 2005. The Dynamics of Transitions in Socio-technical Systems: A Multi-level Analysis of the Transition Pathway from Horse-drawn Carriages to Automobiles (18601930). Technol. Anal. Strateg. Manag. 17, 445-476. doi:10.1080/09537320500357319 
GIZ, 2015. How do we license it? A guide to licensing a mini-grid energy service company in Kenya. GIZ Pro Solar, Nairobi.

Glemarec, Y., 2012. Financing off-grid sustainable energy access for the poor. Energy Policy 47, 87-93. doi:10.1016/j.enpol.2012.03.032

Government of Uttar Pradesh, 2016. Uttar Pradesh Mini Grid Policy. Government of Uttar Pradesh, Lucknow.

Greenwood, R., Suddaby, R.O.Y., 2006. Institutional entrepreneurship in mature fields: the big five accounting firms. Acad. Manag. J. 49, 27-48.

Hansen, U.E., Nygaard, I., 2014. Sustainable energy transitions in emerging economies: The formation of a palm oil biomass waste-to-energy niche in Malaysia 1990-2011. Energy Policy 66, 666-676

Hansen, U.E., Pedersen, M.B., Nygaard, I., 2015. Review of solar PV policies, interventions and diffusion in East Africa. Renew. Sustain. Energy Rev. 46, 236-248. doi:10.1016/j.rser.2015.02.046

Hansen, U.E., Nygaard, I., Romijn, H.A., Wieczorek, A.J., Klerkx, L., 2017. Sustainability transitions in developing countries: Stocktaking, new contributions and a research agenda. Environ. Sci. Policy. doi:10.1016/j.envsci.2017.11.009

Hellsmark, H., Jacobsson, S., 2009. Opportunities for and limits to Academics as System builders-The case of realizing the potential of gasified biomass in Austria. Energy Policy 37, 5597-5611. doi:10.1016/j.enpol.2009.08.023

IEA, 2011. Energy for All: financing access for the poor. OECD, IEA, Paris.

IEA, World Bank, 2015. Progress Toward Sustainable Energy 2015: Global Tracking Framework Report. doi:10.1596/978-1-4648 -0690-2

Ilskog, E., Kjellström, B., Gullberg, M., Katyega, M., Chambala, W., 2005. Electrification cooperatives bring new light to rural Tanzania. Energy Policy 33, 1299-1307. doi:10.1016/j.enpol.2003.12.006

IRENA, 2016. Solar PV in Africa: Costs and Markets. International Renewable Energy Agency (IRENA).

Jolly, S., Raven, R.P.J.M., 2015. Collective institutional entrepreneurship and contestations in wind energy in India. Renew. Sustain. Energy Rev. 42, 999-1011. doi:10.1016/j.rser.2014.10.039

Kapika, J., Eberhard, A., 2013. Kenya: enabling private sector participation in electricity generation, in: Power-Sector Reform and Regulation in Africa: Lessons from Kenya, Tanzania, Uganda, Zambia, Namibia and Ghana. HSRC Press, Cape Town.

Kebede, K.Y., Mitsufuji, T., Choi, E.K., 2014. Looking for innovation system builders: A case of Solar Energy Foundation in Ethiopia. African J. Sci. Technol. Innov. Dev. 6, 289-300. doi:10.1080/20421338.2014.947198

KPLC, 2015. Notes by Dr. Ben Chumo, Kenya Power managing director and chief executive officer, during the press conference on implementation of the last mile project on tuesday 9th, June, 2015. Kenya Power (KPLC).

Lawrence, T.B., Suddaby, R., 2006. Institutions and Institutional Work, in: Clegg, S.R., Hardy, C., Lawrence, T., Nord, W.. (eds.), The SAGE Handbook of Organization Studies. London, p. 215. doi:10.2307/591759

Lee, K., Brewer, E., Christiano, C., Meyo, F., Miguel, E., Podolsky, M., Rosa, J., Wolfram, C., 2016. Barriers to Electrification for 'Under Grid' Households in Rural Kenya. Dev. Eng. 1, 26-35. doi:10.1016/j.deveng.2015.12.001

Markard, J., Truffer, B., 2008. Technological innovation systems and the multi-level 
perspective: Towards an integrated framework. Res. Policy 37, 596-615. doi:10.1016/j.respol.2008.01.004

Markard, J., Suter, M., Ingold, K., 2016. Socio-technical transitions and policy change Advocacy coalitions in Swiss energy policy. Environ. Innov. Soc. Transitions 18, 215237. doi:10.1016/j.eist.2015.05.003

MoEP, 2012. Feed-in-tariffs policy on wind, biomass and small hydrogeothermal, biogas and solar resources generated electricity. Ministry of Energy and Petroleum, Kenya, Nairobi.

Mulwa, E., 2015. Kenya Power brings down connection fee by 50 per cent [WWW Document]. Stand. URL https://www.standardmedia.co.ke/article/2000163754/kenyapower-brings-down-connection-fee-by-50-per-cent (accessed 3.11.17).

Njuguna, J., 2012. Electrification Strategies: 'Stimaloan' credit facilities. Power Point Presentation, Presented to the ESMAP-Cities Alliance Urban / Peri-urban Energy Access Workshop, Washington DC.

Nygaard, I., 2009. Organisation of rural electrification: The case of Burkina Faso, Presentation at PACEAA training seminar, Kigali (RW), 22 Oct, 2009.

Nygaard, I., 2010. Institutional options for rural energy access: Exploring the concept of the multifunctional platform in West Africa. Energy Policy, 38, 1192-1201. DOI: 10.1016/j.enpol.2009.11.009

Nygaard, I., 2012. Rural Electrification Approaches in West Africa: Some Reflections International Workshop on Financial and Institutional Challenges facing Off-grid electrification, De Montfort University, Leicester, United Kingdom, 16/10/2012

Nygaard, I., Dafrallah, T., 2016., Utility led rural electrification in Morocco: combining grid extension, mini-grids, and solar home systems. WIRE Energy Environ. 5, no. 2, pp. 155168. DOI: 10.1002/wene.165

Ockwell, D., Byrne, R., 2015. Improving technology transfer through national systems of innovation: climate relevant innovation-system builders (CRIBs). Clim. Policy 1-19. doi:10.1080/14693062.2015.1052958

Pedersen, M.B., 2016. Deconstructing the concept of renewable energy-based mini-grids for rural electrification in East Africa. WIRE Energy Environ. 5, 570-587. doi:10.1002/wene.205

Perkmann, M., Spicer, A., 2008. How are management fashions institutionalized? The role of institutional work. Hum. Relations 61, 811-844. doi:10.1177/0018726708092406

Raven, R., Kern, F., Verhees, B., Smith, A., 2016. Niche construction and empowerment through socio-political work: A meta-analysis of six low-carbon technology cases. Environ. Innov. Soc. Transitions 18, 164-180. doi:10.1016/j.eist.2015.02.002

Raven, R.P.J.M., 2006. Towards alternative trajectories? Reconfigurations in the Dutch electricity regime. Res. Policy 35, 581-595. doi:10.1016/j.respol.2006.02.001

REA, 2016a. REA News. Rural Energy Authority (REA) Kenya, January, Nairobi.

REA, 2016b. Tender no. REA/2016-2017/NT/027 for design, supply, installation, testing and commissioning of 25 no. $60 \mathrm{kw}$ solar pv-diesel hybrid plants in 25 trading centres in offgrid areas

Rip, A., Kemp, R., 1998. Technological Change, in: Rayner, S., Malone, E.L. (eds.), Human Choice and Climate Change, Vol 2. Battelle Press, Columbus, OH, pp. 237-299.

Ritvala, T., Kleymann, B., 2012. Scientists as Midwives to Cluster Emergence: An Institutional Work Framework. Ind. Innov. 19, 477-497. doi:10.1080/13662716.2012.718875

Rolffs, P., Ockwell, D., Byrne, R. (2015) Beyond technology and finance: pay-as-you-go 
sus-tainable energy access and theories of soci-al change. Environ. Plan. A 47: 26092627. doi:10.1177/0308518X15615368

Schmidt, T.S., Blum, N.U., Sryantoro Wakeling, R., 2013. Attracting private investments into rural electrification: - A case study on renewable energy based village grids in Indonesia. Energy Sustain. Dev. 17, 581-595. doi:10.1016/j.esd.2013.10.001

Schot, J., Geels, F.W., 2008. Strategic niche management and sustainable innovation journeys: theory, findings, research agenda, and policy. Technol. Anal. Strateg. Manag. 20, 537-554. doi:10.1080/09537320802292651

Scott, W.R., 1995. Institutions and organizations. SAGE, Thousand Oaks, CA.

SE4ALL, 2012. Global Tracking Framework. Sustainable Energy for All (SE4ALL).

Shiundu, A., 2016. MPs approve bill to force Kenya Power pay consumers for outages [WWW Document]. Stand. Digit. News. URL http://www.standardmedia.co.ke/m/?articlelD=2000200059\&story_title=mpsapprove-bill-to-force-kenya-power-pay-consumers-for-outages (accessed 11.29.16).

Suri, T., Jack, B., 2012. Reaching the Poor: Mobile Banking and Financial Inclusion [WWW Document]. Slate. URL http://www.slate.com/blogs/future_tense/2012/02/27/m_pesa_ict4d_and_mobile_ba nking_for_the_poor_html

Ulsrud, K., Winther, T., Palit, D., Rohracher, H., 2015. Village-level solar power in Africa: Accelerating access to electricity services through a socio-technical design in Kenya. Energy Res. Soc. Sci. 5, 34-44. doi:10.1016/j.erss.2014.12.009

UNDP, 2011. Towards an 'Energy Plus' approach for the poor: a review of good practices and lessons learned from Asia and the Pacific. United Nations Development Programme (UNDP), Bangkok.

UNEP, 2015. Increasing Private Capital Investment into Energy Access: The Case for Minigrid Pooling Facilities. UNEP, Paris.

Waruru, M., 2015. Solar microgrid firm vies for Kenya's last-mile power customers [WWW Document]. Reuters. URL http://uk.reuters.com/article/2015/07/10/kenya-electricitysolar-idUKL8NOZQ1SZ20150710 (accessed 10.6.15).

Wiemann, M., Lecoque, D., 2015. SE4All High Impact Opportunity Clean Energy Mini-grids: Mapping of clean energy mini-grid support providers and programmes. Sustainable Energy for All (SE4ALL).

Williams, N.J., Jaramillo, P., Taneja, J., Ustun, T.S., 2015. Enabling private sector investment in microgrid-based rural electrification in developing countries: A review. Renew. Sustain. Energy Rev. 52, 1268-1281. doi:10.1016/j.rser.2015.07.153

World Economic Forum, 2013. The Green Investment Report: The ways and means to unlock private finance for green growth. World Economic Forum, Geneva.

\footnotetext{
i Staff interview \# 5

ii Key informant \# 3, \# 5

iii Staff interview \# 2

iv Staff interview \# 2

$\checkmark$ Staff interview \# 4

vi Staff interview \# 5

vii Staff interview \# 5

viii Staff interview \# 5

ix Staff interview \# 7
} 